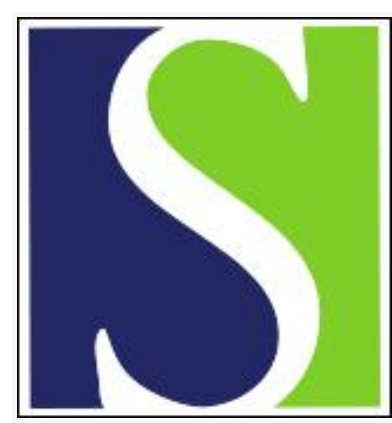

Scand J Work Environ Health 1990;16(3):195-202

https://doi.org/10.5271/sjweh.1794

Issue date: 01 Jun 1990

Smoking habits and lifetime occupational exposure to gases or dusts, including asbestos and quartz, in a Norwegian community.

by Bakke P, Gulsvik A, Eide GE, Hanoa R

Affiliation: Department of Thoracic Medicine, University of Bergen, Norway.

This article in PubMed: www.ncbi.nlm.nih.gov/pubmed/2382122

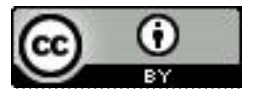




\title{
Smoking habits and lifetime occupational exposure to gases or dusts, including asbestos and quartz, in a Norwegian community
}

\author{
by Per Bakke, MD, ${ }^{1}$ Amund Gulsvik, MD, ${ }^{1}$ Geir E Eide, MSc, ${ }^{2}$ Rolf Hanoa, MD ${ }^{1}$
}

\begin{abstract}
BAKKE P, GULSVIK A, EIDE GE, HANOA R. Smoking habits and lifetime occupational exposure to gases or dusts, including asbestos and quartz, in a Norwegian community. Scand $J$ Work Environ Health 1990;16:195-202. Past or present occupational airborne exposure was recorded with a self-administered questionnaire sent to a random sample $(\mathrm{N}=4992)$ of the 15 - to 70 -year-old population of Hordaland County, Norway. Completed questionnaires were returned by $90 \%$ of the sample. The respondents comprised $39 \%$ smokers, $20 \%$ ex-smokers, and $41 \%$ nonsmokers. Altogether $46 \%$ of the men and $12 \%$ of the women had a history of occupational gas or dust exposure. Occupational asbestos exposure was reported by $10 \%$ of the men and $0.4 \%$ of the women, and quartz exposure had been experienced by $8 \%$ of the men and $0.4 \%$ of the women. Smokers with a history of asbestos exposure represented $5 \%$ of the male population. Thirty percent of the smokers reported having been advised to stop smoking by a physician. The asbestos-exposed smokers had not received such advice more often than the smokers not exposed to asbestos. The findings indicate that airborne occupational exposure is widespread in the Norwegian County of Hordaland.
\end{abstract}

Key terms: occupational dust exposure, occupational gas exposure, population survey, smoking cessation advice.

Cigarette smoking and occupational exposure to organic or inorganic dust, fumes, and gas are known causes of obstructive or restrictive lung disorders and lung cancer $(1,2)$.

In a Norwegian questionnaire survey of 21453 men 40 years of age or more, $18 \%$ reported previous exposure to asbestos (3). No population-based information is available on occupational asbestos exposure among women and younger men and on quartz exposure in general in northwestern Europe.

Asbestos exposure and cigarette smoking have a synergistic effect on the risk for lung cancer (4). For asbestos-exposed smokers the single most important intervention that would reduce their disease risk is the cessation of smoking. It is not known whether physicians advise this high-risk group to stop smoking more often than unexposed smokers.

The objectives of the present study were (i) to estimate the prevalence of smokers in the population, according to two different definitions of smoking habits, (ii) to examine the lifetime prevalence of occupational gas or dust exposure, including asbestos and quartz, in the community, (iii) to examine how official employment data from the 1980 census predict an individual's risk of lifetime occupational exposure to airborne pollutants, and (iv) to assess whether a history

\footnotetext{
1 Department of Thoracic Medicine, University of Bergen, Bergen, Norway.

2 Section for Medical Informatics and Statistics, University of Bergen, Bergen, Norway.
}

Reprint requests to: Dr P Bakke, Department of Thoracic Medicine, Haukeland Hospital, N-5021 Bergen, Norway. of occupational asbestos exposure is a predictor of a smoker having received advice to stop smoking from a physician.

\section{Subjects and methods}

The survey population of the County of Hordaland comprised all persons between 15 and 70 years and included 267304 subjects on 31 December 1984. The working population of the County was occupied in industry $(21 \%)$, construction $(9 \%)$, agriculture and fishing $(5 \%)$, and private and public services $(64 \%)$ (5). The County contains 34 municipalities, of which Bergen is the only urban one, with half the population of the County. A postal questionnaire was sent from September to December 1985 to a random sample of 4992 persons of the survey population. The response rate was $90 \%$.

The questionnaire asked for information on smoking habits and tobacco consumption, and smokers were asked if any physician had advised them to stop smoking. The wording of these questions, and the wording of the questions on occupational exposure to airborne pollutants, including asbestos and quartz, are given in the appendix. Only past or present employees or selfemployed persons were asked to answer the occupational exposure questions.

Smokers were defined as those persons who smoked daily at the time of the study. Ex-smokers were persons who had smoked daily and had given it up. Nonsmokers were persons who had never smoked daily (6). If the daily cigarette consumption was stated by a 
range, eg, 10-15, the mean was calculated and used for the analysis. The prevalences of smoking habits determined with these standard definitions were compared with those observed when an alternative set of definitions was used (7). The alternative definitions were as follows: smokers were those persons who had been smoking daily for more than one year, including those who had stopped less than 12 months prior to the study; ex-smokers were those who had been smoking for more than one year and had given it up at least one year prior to the survey; nonsmokers were those who had never smoked daily for as much as one year.

Possible factors associated with previous or present occupational exposure to airborne pollutants were evaluated with the use of a multiple logistic regression analysis (8). Sex, age, smoking habits, and the 1980 census data relating to that part of the working population employed in the manufacturing and construction industries in the 34 respective municipalities were used as the independent variables. Thus each subject was characterized by the percentage of workers occupied in these industries in his or her municipality. The portion of the working population occupied in manufacturing in the municipalities varied from 4 to $40 \%$, and the corresponding figures for the construction industry were 6 to $34 \%$ (9). The manufacturing and construction industries were defined according to the Standard Industrial Classification (10).

Factors that might influence a physician's tendency to advise smokers to quit were analyzed in a logistic regression model. Duration of smoking and daily cigarette consumption, a history of occupational exposure to airborne pollutants, sex, age, and urban-rural area of residence were used as the independent variables.

Each logistic regression analysis started with all the independent variables within the model. Only significant variables were kept in the final model. The entry and exit levels were set at $\mathbf{P}=\mathbf{0 . 0 1}$. An analysis of variance was used to test for differences between the means of the groups. Mantel-Haenszel statistics were applied to estimate stratified associations between two dichotomous variables. Rates of smoking habits by oc- cupational exposure status were adjusted for age by the direct method with the age distribution of the population of Hordaland County at the end of 1985 as the reference (11). All the analyses were performed with programs of the BMDP (biomedical data package) statistical software (8).

\section{Results}

Altogether $95 \%$ of the respondents to the questionnaire answered all the questions on smoking habits. The completion rate of the questions on smoking habits fell by increasing age among both the men and the women, being $93 \%$ in the age group of 50-69 years. The question on occupational dust or gas exposure was answered by $99 \%$ of the men and $96 \%$ of the women who were currently employees or self-employed. The completion rates to the questions on whether or not the subjects had been exposed to asbestos or quartz were higher than $98 \%$ for both sexes.

The prevalences of smokers and nonsmokers differed within $1 \%$ between the two criteria of smoking habits. The frequency of unknown smoking habits was $1 \%$ when the standard definition was used and $4 \%$ with the alternative definition. The latter required information on duration of smoking and time since smoking cessation, and $3 \%$ of the respondents did not answer these questions. In the further analyses we therefore used the data collected according to the standard criteria for smoking habits.

The overall prevalences of smokers, ex-smokers, and nonsmokers in the population of Hordaland aged 15-70 years were 39,20 , and $41 \%$, respectively. Smoking was more frequent $(\mathrm{P}<0.01)$ among the men $(42 \%)$ than among the women $(35 \%)$ (table 1$)$. In the age group 15-29 years this sex difference disappeared. The prevalence of smokers showed no age trend among the men. Among the women it fell with increasing age, being almost two times higher $(\mathrm{P}<0.01)$ in the age group 15-29 years as in the age group 50-69 years. The prevalence of ex-smokers increased with age

Table 1. Smoking habits by sex and age of the population $(\mathrm{N}=4469)$ in Hordaland County in 1985.

\begin{tabular}{|c|c|c|c|c|c|c|c|c|}
\hline \multirow{3}{*}{ Smoking status ${ }^{a}$} & \multicolumn{8}{|c|}{ Age group (years) } \\
\hline & \multicolumn{2}{|c|}{$15-29$} & \multicolumn{2}{|c|}{$30-49$} & \multicolumn{2}{|c|}{$50-69$} & \multicolumn{2}{|c|}{$15-70$} \\
\hline & $\begin{array}{c}\text { Men } \\
(\mathbf{N}=771) \\
(\%)\end{array}$ & $\begin{array}{c}\text { Women } \\
(\mathrm{N}=725) \\
(\%)\end{array}$ & $\begin{array}{c}\text { Men } \\
(\mathrm{N}=824) \\
(\%)\end{array}$ & $\begin{array}{c}\text { Women } \\
(\mathrm{N}=823) \\
(\%)\end{array}$ & $\begin{array}{c}\text { Men } \\
(\mathrm{N}=577) \\
(\%)\end{array}$ & $\begin{array}{c}\text { Women } \\
(N=637) \\
(\%)\end{array}$ & $\begin{array}{c}\text { Men } \\
(N=2220) \\
(\%)\end{array}$ & $\begin{array}{c}\text { Women } \\
(\mathrm{N}=2249) \\
(\%)\end{array}$ \\
\hline Smokers & 41 & 42 & 45 & 39 & 40 & 24 & 42 & 35 \\
\hline $\begin{array}{l}1-9 \text { cigarettes } / \mathrm{d} \\
10-19 \text { cigarettes } / \mathrm{d} \\
\geq 20 \text { cigarettes } / \mathrm{d} \\
\text { Unknown type and amount }\end{array}$ & $\begin{array}{r}6 \\
23 \\
10 \\
1\end{array}$ & $\begin{array}{r}12 \\
24 \\
4 \\
2\end{array}$ & $\begin{array}{r}4 \\
21 \\
16 \\
3\end{array}$ & $\begin{array}{r}8 \\
22 \\
6 \\
2\end{array}$ & $\begin{array}{r}5 \\
16 \\
17 \\
2\end{array}$ & $\begin{array}{r}7 \\
10 \\
3 \\
4\end{array}$ & $\begin{array}{r}5 \\
20 \\
12 \\
4\end{array}$ & $\begin{array}{r}9 \\
19 \\
4 \\
3\end{array}$ \\
\hline Ex-smokers & 11 & 12 & 25 & 21 & 37 & 14 & 24 & 16 \\
\hline Nonsmokers & 48 & 45 & 30 & 39 & 22 & 59 & 34 & 47 \\
\hline Unknown habits & 1 & 1 & 0 & 1 & 0 & 3 & 0 & 2 \\
\hline
\end{tabular}

a Pipe and/or cigar smokers were not considered a separate group, but they were included in the numbers under smokers. 
Table 2. Previous or current occupational exposure of the Hordaland County population $(\mathrm{N}=4469)$ to gases or dusts, asbestos, and quartz, by sex and age in 1985. ( $-=$ magnitude nil, $0=$ less than $0.5 \%$ )

\begin{tabular}{|c|c|c|c|c|c|c|}
\hline Age group (years) & $\mathbf{N}$ & $\begin{array}{c}\text { Asbestos } \\
\text { and quartz } \\
\text { exposure } \\
(\%)\end{array}$ & $\begin{array}{c}\text { Only } \\
\text { asbestos } \\
\text { exposure } \\
(\%)\end{array}$ & $\begin{array}{c}\text { Only } \\
\text { quartz } \\
\text { exposure } \\
(\%)\end{array}$ & $\begin{array}{c}\text { Gas or dust } \\
\text { exposure other } \\
\text { than asbestos } \\
\text { or quartz } \\
(\%)\end{array}$ & $\begin{array}{c}\text { Gas or } \\
\text { dust } \\
\text { exposure } \\
(\%)\end{array}$ \\
\hline \multicolumn{7}{|l|}{$15-29$} \\
\hline Men & 771 & 1 & 7 & 4 & 32 & 44 \\
\hline Women & 725 & 0 & 0 & 0 & 13 & 13 \\
\hline \multicolumn{7}{|l|}{$30-49$} \\
\hline $\begin{array}{l}\text { Men } \\
\text { Women }\end{array}$ & $\begin{array}{l}824 \\
823\end{array}$ & $\frac{2}{-}$ & $\begin{array}{l}8 \\
1\end{array}$ & $\begin{array}{l}7 \\
1\end{array}$ & $\begin{array}{l}31 \\
13\end{array}$ & $\begin{array}{l}48 \\
14\end{array}$ \\
\hline \multicolumn{7}{|l|}{$50-69$} \\
\hline $\begin{array}{l}\text { Men } \\
\text { Women }\end{array}$ & $\begin{array}{l}577 \\
637\end{array}$ & $\frac{2}{-}$ & $\begin{array}{c}9 \\
-\end{array}$ & $\begin{array}{l}8 \\
0\end{array}$ & $\begin{array}{r}25 \\
9\end{array}$ & $\begin{array}{r}44 \\
9\end{array}$ \\
\hline \multicolumn{7}{|l|}{$15-70$} \\
\hline $\begin{array}{l}\text { Men } \\
\text { Women }\end{array}$ & $\begin{array}{l}2220 \\
2249\end{array}$ & $\begin{array}{l}2 \\
0\end{array}$ & $\begin{array}{l}8 \\
0\end{array}$ & $\begin{array}{l}6 \\
0\end{array}$ & $\begin{array}{l}29 \\
11\end{array}$ & $\begin{array}{l}46 \\
12\end{array}$ \\
\hline
\end{tabular}

among the men $(\mathrm{P}<0.01)$, whereas no age trend was evident for the women.

For smokers the mean daily cigarette consumption was 15.2 (SD 7.4) for the men and 12.2 (SD 5.8) for the women. Heavy smokers ( $\geq 20$ cigarettes/d) were three times more common among the men than among the women $(\mathrm{P}<0.01)$. In the age group $15-19$ years there was no significant sex difference regarding daily cigarette consumption. No urban-rural differences were observed regarding the prevalences of smoking for either sex after adjustment for age. However, urban male and female smokers consumed two and one cigarettes more $(P<0.05)$ per day, respectively, than rural smokers of the same sex. Of the smokers $16 \%$ indicated a range, eg, 10-15, for their daily cigarette consumption. If the largest figure were used, and not the calculated mean, the overall daily cigarette consumption would increase by 0.3 cigarettes per smoker.

The ratio between the ex-smokers and ever smokers (ex-smokers and smokers) expresses the success of smokers quitting smoking. Among our respondents the ratio was 0.34 , and it did not vary for the two sexes or for the subjects occupationally exposed to airborne pollutants in comparison with the unexposed persons.

Altogether $46 \%$ of the men and $12 \%$ of the women had a history of occupational gas or dust exposure (table 2). Of the 1611 men and 1157 women who were enployees or self-employed, $51 \%$ of the men and $15 \%$ of the women reported past or present occupational exposure to gas or dust. Occupational exposure to asbestos and quartz was reported by 10 and $8 \%$ of the men, respectively, and $2 \%$ of the men stated exposure to both minerals. Of the women $0.4 \%$ had been exposed to asbestos and $0.4 \%$ to quartz. Of the asbestos-exposed men $56 \%$ were younger than 40 years, while eight of the 10 asbestos-exposed women were in this age group. The lifetime prevalence of quartz exposure increased with age, being twice as common $(\mathrm{P}<0.01)$ in the oldest as in the youngest age
Table 3. Decade of first exposure for the 232 subjects who reported ever having been occupationally exposed to asbestos, from sample of the population aged $15-70$ years in Hordaland County, Norway, in 1985.

\begin{tabular}{lccrr}
\hline \multirow{2}{*}{$\begin{array}{l}\text { First } \\
\text { exposure }\end{array}$} & $\begin{array}{c}\text { Men } \\
(\mathrm{N})\end{array}$ & $\begin{array}{c}\text { Women } \\
(\mathrm{N})\end{array}$ & \multicolumn{2}{c}{ Total } \\
\cline { 4 - 6 } & & & $\mathrm{N}$ & $\%$ \\
\hline $1930-1939$ & 5 & - & 5 & 2 \\
$1940-1949$ & 15 & - & 15 & 6 \\
$1950-1959$ & 28 & - & 28 & 12 \\
$1960-1969$ & 41 & - & 41 & 18 \\
$1970-1979$ & 73 & 1 & 74 & 32 \\
$1980-$ & 40 & 3 & 43 & 19 \\
Unknown & 20 & 6 & 26 & 11 \\
\hline
\end{tabular}

Table 4. Duration of exposure for the 232 subjects who reported ever having been occupationally exposed to asbestos and for the 196 subjects who reported ever having been occupationally exposed to quartz, from sample of the population aged $15-70$ years in Hordaland County, Norway, in 1985.

\begin{tabular}{ccrlrr}
\hline \multirow{2}{*}{$\begin{array}{l}\text { Duration of } \\
\text { exposure (years) }\end{array}$} & \multicolumn{2}{c}{ Asbestos } & & \multicolumn{2}{c}{ Quartz } \\
\cline { 2 - 3 } \cline { 5 - 6 } & $\mathrm{N}$ & $\%$ & & $\mathrm{~N}$ & $\%$ \\
\hline$<5$ & 93 & 40 & 87 & 44 \\
$5-14$ & 60 & 26 & 55 & 28 \\
$15-24$ & 16 & 7 & 19 & 10 \\
$\geq 25$ & 11 & 5 & 18 & 9 \\
Unknown & 52 & 22 & 17 & 9 \\
\hline
\end{tabular}

group (table 2). No age trends were observed regarding the lifetime prevalence of exposure to gases or dusts, including asbestos. Among the men occupational exposure to gases or dusts, including quartz, was more prevalent $(\mathrm{P}<0.01)$ in the rural than the urban areas after adjustment for age, while the rates for asbestos exposure did not show any urban-rural difference. Among the women occupational gas or dust exposure did not vary with urban-rural area of residence.

Half of the asbestos-exposed subjects reported their first exposure after 1970; all of the exposed women were among these subjects (table 3 ). Most $(80 \%)$ of the persons exposed to asbestos reported the exposure 
to be light, whereas $16 \%$ considered it moderate, and $4 \%$ believed it to be heavy. None of the women reported heavy exposure to asbestos. Almost half of the persons with a history of asbestos or quartz exposure had been exposed for less than five years, while less than $10 \%$ had been exposed for more than 25 years (table 4).

For both the men and the women the age-adjusted smoking rates and the daily cigarette consumption were higher $(\mathrm{P}<0.01)$ among the subjects occupationally exposed to gases or dusts than among the unexposed persons (tables 5 and 6). The individuals exposed to as- bestos and quartz had higher $(\mathrm{P}<0.05)$ smoking rates than those with other gas or dust exposures (table 5). Current smoking and a history of airborne occupational exposure to gases or dusts were reported by $22 \%$ of the men and $5 \%$ of the women. Previous or present asbestos exposure and current smoking were recorded for $5 \%$ of the men and $0.2 \%$ of the women.

After adjustment for sex, age, and smoking habits (table 6), there was an association between lifetime prevalence of occupational gas or dust exposure and the percentage of individuals occupied in manufacturing within the municipality. There was also a rela-

Table 5. Age-adjusted percentages of smoking habits of the male and female population aged $15-70$ years $(\mathrm{N}=4469)$ in Hordaland county by occupational exposure status in 1985 . ( $-=$ magnitude nil, $0=$ less than $0.5 \%)$

\begin{tabular}{|c|c|c|c|c|c|c|c|c|c|c|}
\hline \multirow{2}{*}{ Smoking } & \multirow{2}{*}{$\begin{array}{c}\begin{array}{c}\text { Asbestos } \\
\text { and } \\
\text { quartz } \\
\text { exposure }\end{array} \\
\begin{array}{c}\text { Men } \\
(\mathrm{N}=45) \\
(\%)\end{array}\end{array}$} & \multirow{2}{*}{$\begin{array}{c}\begin{array}{c}\text { Only } \\
\text { asbestos } \\
\text { exposure }\end{array} \\
\begin{array}{c}\text { Men } \\
(\mathrm{N}=177) \\
(\%)\end{array}\end{array}$} & \multirow{2}{*}{$\begin{array}{c}\begin{array}{c}\text { Only } \\
\text { quartz } \\
\text { exposure }\end{array} \\
\begin{array}{c}\text { Men } \\
(N=141) \\
(\%)\end{array}\end{array}$} & \multirow{2}{*}{$\begin{array}{c}\text { Gas or dust } \\
\text { exposure } \\
\text { other than } \\
\text { asbestos } \\
\text { or quartz } \\
\begin{array}{c}\text { Men } \\
(N=651) \\
(\%)\end{array}\end{array}$} & \multicolumn{2}{|c|}{$\begin{array}{c}\text { Gas or dust } \\
\text { exposure }\end{array}$} & \multicolumn{2}{|c|}{$\begin{array}{c}\text { No } \\
\text { exposure }\end{array}$} & \multicolumn{2}{|c|}{$\begin{array}{c}\text { No } \\
\text { answer }\end{array}$} \\
\hline & & & & & $\begin{array}{c}\text { Men } \\
(\mathrm{N}=1014) \\
(\%)\end{array}$ & $\begin{array}{c}\text { Women } \\
(N=269) \\
(\%)\end{array}$ & $\begin{array}{c}\text { Men } \\
(\mathrm{N}=1023) \\
(\%)\end{array}$ & $\begin{array}{c}\text { Women } \\
(\mathrm{N}=1513) \\
(\%)\end{array}$ & $\begin{array}{c}\text { Men } \\
(N=183) \\
(\%)\end{array}$ & $\begin{array}{c}\text { Women } \\
(N=467) \\
(\%)\end{array}$ \\
\hline Smokers & 48 & 51 & 58 & 44 & 47 & 43 & 40 & 36 & 43 & 32 \\
\hline $\begin{array}{l}1-9 \text { cigarettes } / d \\
10-19 \text { cigarettes } / d \\
\geq 20 \text { cigarettes } / d \\
\text { Unknown type } \\
\text { and amount }\end{array}$ & $\begin{array}{r}3 \\
22 \\
20\end{array}$ & $\begin{array}{r}4 \\
27 \\
16\end{array}$ & $\begin{array}{r}6 \\
30 \\
18\end{array}$ & $\begin{array}{r}5 \\
22 \\
14\end{array}$ & $\begin{array}{r}5 \\
23 \\
16\end{array}$ & $\begin{array}{r}11 \\
24 \\
6\end{array}$ & $\begin{array}{r}6 \\
19 \\
10\end{array}$ & $\begin{array}{r}10 \\
20 \\
4\end{array}$ & $\begin{array}{r}7 \\
19 \\
11\end{array}$ & $\begin{array}{r}9 \\
14 \\
4\end{array}$ \\
\hline Ex-smokers & 23 & 17 & 20 & 30 & 26 & 15 & 21 & 16 & 28 & 15 \\
\hline Nonsmokers & 29 & 32 & 20 & 25 & 26 & 42 & 39 & 46 & 28 & 51 \\
\hline Unknown habits & 0 & 0 & 2 & 0 & 0 & - & 0 & 1 & 0 & 3 \\
\hline
\end{tabular}

Table 6. Adjusted odds ratios (OR) with the $95 \%$ confidence interval $(95 \% \mathrm{Cl}$ ) for previous or current occupational exposure to airborne pollutants by sex, age, smoking habits, and employment data of the 1980 census for a sample of the population aged 15-70 years in Hordaland County, Norway, in 1985.

\begin{tabular}{|c|c|c|c|c|c|c|c|c|c|}
\hline \multirow[t]{2}{*}{$\begin{array}{l}\text { Independent } \\
\text { variables }\end{array}$} & \multirow[t]{2}{*}{$\mathrm{N}^{\mathrm{a}}$} & \multicolumn{2}{|c|}{ Gases or dusts } & \multicolumn{2}{|c|}{ Asbestos } & \multicolumn{2}{|c|}{ Quartz } & \multicolumn{2}{|c|}{$\begin{array}{l}\text { Gases or dusts } \\
\text { other than as- } \\
\text { bestos or quartz }\end{array}$} \\
\hline & & OR & $95 \% \mathrm{Cl}$ & OR & $95 \% \mathrm{Cl}$ & OR & $95 \% \mathrm{Cl}$ & OR & $95 \% \mathrm{Cl}$ \\
\hline \multicolumn{10}{|l|}{ Sex } \\
\hline $\begin{array}{l}\text { Women } \\
\text { Men }\end{array}$ & $\begin{array}{l}2146 \\
2112\end{array}$ & $\begin{array}{l}1 \\
5.6\end{array}$ & $4.8-6.5$ & $\begin{array}{c}1 \\
24.0\end{array}$ & $12.7-45.3$ & $\stackrel{1}{17.4}$ & $9.1-33.1$ & $\begin{array}{l}1 \\
3.0\end{array}$ & $2.5-3.5$ \\
\hline \multicolumn{10}{|l|}{ Age } \\
\hline $\begin{array}{l}x \\
x+10 \text { years }\end{array}$ & $\begin{array}{l}\cdots \\
\cdots\end{array}$ & $\begin{array}{l}1 \\
1.0\end{array}$ & $0.9-1.0$ & $\begin{array}{l}1 \\
1.0\end{array}$ & $0.9-1.1$ & $\begin{array}{l}1 \\
1.2\end{array}$ & $1.1-1.3$ & $\begin{array}{l}1 \\
0.9\end{array}$ & $0.9-1.0$ \\
\hline \multicolumn{10}{|l|}{ Smoking habits } \\
\hline $\begin{array}{l}1-9 \text { cigarettes } / \mathrm{d} \\
10-19 \text { cigarettes } / \mathrm{d} \\
\geq 20 \text { cigarettes } / \mathrm{d}\end{array}$ & $\begin{array}{l}320 \\
880 \\
368\end{array}$ & $\begin{array}{l}1.4 \\
1.9 \\
2.5\end{array}$ & $\begin{array}{l}1.1-1.9 \\
1.6-2.3 \\
1.9-3.2\end{array}$ & $\begin{array}{l}1.0 \\
1.2 \\
1.9\end{array}$ & $\begin{array}{l}0.5-1.5 \\
0.8-1.8 \\
1.3-2.8\end{array}$ & $\begin{array}{l}1.5 \\
1.8 \\
2.5\end{array}$ & $\begin{array}{l}0.7-3.0 \\
1.2-2.7 \\
1.6-4.1\end{array}$ & $\begin{array}{l}1.4 \\
1.7 \\
1.8\end{array}$ & $\begin{array}{l}1.0-1.9 \\
1.4-2.1 \\
1.4-2.4\end{array}$ \\
\hline $\begin{array}{l}\text { Ex-smokers } \\
\text { Nonsmokers }\end{array}$ & $\begin{array}{r}877 \\
1813\end{array}$ & $\begin{array}{l}1.7 \\
1\end{array}$ & $\begin{array}{c}1.4-2.1 \\
\cdots\end{array}$ & $\begin{array}{l}1.0 \\
1\end{array}$ & $\begin{array}{c}0.7-1.4 \\
\ldots\end{array}$ & $\begin{array}{l}1.4 \\
1\end{array}$ & $\frac{0.9-2.1}{\ldots}$ & $\begin{array}{l}1.9 \\
1\end{array}$ & $\begin{array}{c}1.5-2.3 \\
\ldots\end{array}$ \\
\hline \multicolumn{10}{|l|}{$\begin{array}{l}\text { Industrial manu- } \\
\text { facturing }^{\mathrm{b}}\end{array}$} \\
\hline $\begin{array}{l}x \\
x+10 \% \text { points }\end{array}$ & $\because$ & $\begin{array}{l}1 \\
1.3\end{array}$ & $1.2-1.5$ & $\begin{array}{l}1 \\
1.1\end{array}$ & $0.9-1.4$ & $\begin{array}{l}1 \\
1.0\end{array}$ & $0.8-1.3$ & $\begin{array}{l}1 \\
1.3\end{array}$ & $1.2-1.5$ \\
\hline \multicolumn{10}{|l|}{$\begin{array}{l}\text { Construction } \\
\text { industryc }\end{array}$} \\
\hline $\begin{array}{l}X \\
X+10 \% \text { points }\end{array}$ & $\begin{array}{l}\cdots \\
\cdots\end{array}$ & $\begin{array}{l}1 \\
1.4\end{array}$ & $0.9-1.6$ & $\begin{array}{l}1 \\
1.1\end{array}$ & $0.7-1.8$ & $\begin{array}{l}1 \\
2.3\end{array}$ & $1.6-3.4$ & $\begin{array}{l}1 \\
1.1\end{array}$ & $0.8-1.4$ \\
\hline
\end{tabular}

a 211 subjects with unknown smoking habits, cigar and/or pipe smokers, or smokers with unknown cigarette consumption were not included in the analysis.

b Percentage of the municipality's work force occupied in manufacturing.

c Percentage of the municipality's work force occupied in the construction industry. 
tionship between the lifetime prevalence of occupational quartz exposure and the percentage of individuals occupied in the construction industry. The proportion of manufacturing and construction workers in the work force of the municipality did not predict the individual's risk for lifetime occupational asbestos exposure.

Of the current smokers, $30 \%$ reported that they had been advised to quit smoking by a physician. A 10-year increase in smoking duration and an increase in daily consumption by 10 cigarettes raised the adjusted odds ratios for having received such advice by 1.3 [95\% confidence interval $(95 \% \mathrm{CI}) 1.2-1.4]$ and $1.4(95 \%$ CI 1.2-1.7), respectively. A history of occupational exposure to gases, dusts, asbestos, or quartz and the sex, age, and area of residence were not predictors of smokers having received advice from a physician to quit smoking.

\section{Discussion}

Answers to our questions on smoking habits have been compared with the serum thiocyanate levels in a Norwegian community study (12). A considerable overlap in serum thiocyanate levels between smokers and nonsmokers was observed. This finding may indicate a misclassification in self-reported smoking habits. In a community study in England (13) $3 \%$ of self-reported nonsmokers had high saliva cotinin levels that suggested their statement on smoking habits was false. The bias of underreporting may become an increasing problem as the social pressure to stop smoking increases.

Examining the prevalence of occupational exposure through the use of a self-administered questionnaire is an inexpensive method; however, it may easily be subject to misclassification. For Norwegian men over 40 years of age our question on asbestos exposure had a sensitivity of $45 \%$ and a specificity of $97 \%$ (3), figures indicating that the rate of exposed subjects was minimum. The consistency of information on occupational gas or dust exposure and quartz exposure in community surveys has not been validated (14-16).

Our study shows that smoking rates, daily cigarette consumption, and age at the initiation of smoking tend to equalize between the sexes. In a questionnaire survey of 58867 subjects aged $20-49$ years in three Norwegian counties in 1974-1976 (6), smokers represented $55 \%$ of the men and $43 \%$ of the women compared with $45 \%$ of the men and $43 \%$ of the women of identical age in our study. Smoking was less prevalent among the men in our study than in population studies made in Oslo in 1972 (7) and in Tromsø in 1974 (17). Data from the Norwegian National Council on Smoking and Health also indicate that the smoking rate decreased for men during the period 1974-1987, while for women it increased (18). In Sweden (18) and Denmark (19) the prevalence of smokers has fallen for both sexes, but more so for the men than for the women.
The equalizing smoking rates between the sexes may indicate that men and women have responded differently to anti-smoking campaigns. Public campaigns against smoking have two objectives, ie, to encourage people not to take up smoking and to make smokers quit. In the present study the ratio between ex-smokers and ever smokers (smokers and ex-smokers) did not differ between the men and women after adjustment for age and smoking duration. This finding may indicate that the public health message to quit smoking has reached men and women to the same degree, whereas the message of not to start smoking has been more successful among the men. The most recent Surgeon General's report of the United States Department of Health and Human Services (20) recommends that campaigns to prevent smoking pay special attention to young women.

In urban areas of the United States, prevalences of occupational airborne exposure vary from 30 to $57 \%$ among men $(14,15)$ and from 16 to $19 \%$ among women (15). In a Polish study (16) including 1824 subjects aged 19-70 years and drawn at random from an urban population, $30 \%$ of the men and $13 \%$ of the women reported occupational dust exposure. Differences in survey populations and methods of data collection make comparisons of the rates of exposed subjects difficult. However, these studies, as does ours, all show that occupational exposure to airborne agents is widespread in the general population.

The present study failed, as did the aforementioned American study (15), to show an increase in lifetime occupational exposure to gases or dusts with age. This failure is probably due to elderly people tending to forget previous exposures. Other explanations may be that younger people know more about the hazards of occupational pollutants, are less willing to tolerate them, and are more ready to report on them than elderly people. The prevalence rates of the young people indicate that occupational exposure to gases or dusts will remain a problem as risk factors for airway diseases for many decades to come.

Indirect methods may be used to estimate the frequency of occupational asbestos and quartz exposure in the community. Norway has never produced asbestos, and its import peaked in 1971 at $12000 \mathrm{t}$, and was only $200 \mathrm{t}$ in 1985 (T Braaten, The Norwegian Labour Inspectorate, personal communication). However, today's import of asbestos tells very little of exposure due to secondhand contact with the material. Using the number of jobs in which asbestos exposure is likely to occur, Nicholson et al have estimated that approximately $30 \%$ of the men over 40 years of age in the United States may have been exposed to asbestos (21). Screening programs with chest radiography revealed that $1-2 \%$ of the Swedish (22) and Norwegian (23) populations above 40 years of age have pleural plaques attributable to asbestos exposure. However, the long latency between exposure and the development of pleural plaques and the method's low sensitivity for 
detecting pleural plaques (24) limit the feasibility of the results. Regional variations in the occurrence of pleural plaques (23) and mesothelioma (25) may indicate variations in the frequency and level of asbestos exposure. Pleural plaques were observed in $17 \%$ of 402 consecutive autopsies of subjects above 40 years of age in Vest-Agder County, Norway (26). Measures of asbestos and quartz exposure in the future may be the counting of asbestos fibers (27) and silica particles (28) in autopsy material. The presence of asbestos bodies in bronchial alveolar lavage is a good marker of occupational asbestos exposure (29).

The age-standardized rates of asbestos-exposed men above 40 years of age was higher in Telemark $(18 \%)$ (3) than in the present study $(10 \%)$. There may be several explanations for the discrepancy in rates between the two studies. First, the degree of industrialization of the areas investigated in the two studies differed. The Telemark study comprised seven industrialized and two rural municipalities, whereas only 19 of the 34 municipalities of Hordaland are industrialized (30). However, we did not find that the rates of asbestos-exposed subjects varied with the percentage of the municipality's work force occupied in manufacturing and thereby with the degree of industrialization. This finding may indicate that it is the type of industry rather than the degree of industrialization that predicts the individual's risk of occupational asbestos exposure. Second, the letter accompanying the distributed questionnaire of the Telemark study mentioned that the purpose of the study was to examine the occurrence of asbestos exposure, while asbestos exposure was not mentioned in the accompanying letter of our study. Finally, there may be regional differences in people's knowledge of the hazards of asbestos exposure and which work processes are related to it.

The Telemark study estimated that $41 \%$ of the expected lung cancers in the following 10 years will occur among smokers previously exposed to asbestos. This estimate was based on the relative risks for lung cancers obtained from Hammond et al's study (4) on insulation workers. These workers were highly exposed to asbestos, and one must assume that the results are not generalizable to a general population sample. However, if these relative risks for lung cancer are applied to the male population aged $40-69$ years in Hordaland County, $32 \%$ of the expected lung cancers will occur among smokers with past asbestos exposure. These persons represent $5 \%$ of the male population in this age group. The extent to which a positive answer to a question on asbestos exposure represents a risk for lung cancer is not clear. Nonetheless, asbestos-exposed smokers identified by postal questionnaire surveys may be an important target group for smoking cessation campaigns.

Less than $1 \%$ of the women aged $15-70$ years in the County of Hordaland have been occupationally exposed to asbestos or quartz. In $\mathbf{4 7 0 0}$ cases of silicosis reported to the Swedish Pneumoconiosis Registry,
$1 \%$ involved women (31). Of the 134 cases of malignant mesothelioma reported to the Norwegian Cancer Registry during 1970-1979 (32), cases related to occupational exposure to asbestos were 22 times more frequent among the men than the women. This figure is in crude agreement with the male-female ratio of 25 for the frequency of occupational asbestos exposure in the present study. The low number of women exposed to asbestos or quartz indicates that screening for mineral pneumoconioses in the female population should be given low priority.

The strong covariation between smoking habits and gas or dust exposure may be explained by high cigarette consumption and rates of occupational exposure both being associated with low socioeconomic status (33). Furthermore, subjects who are susceptible to cigarette smoke may tend to avoid occupations with exposure to air pollutants.

Physicians' influence with respect to helping people quit smoking has been documented in several studies (34). Approximately $80 \%$ of a Nordic population sees a physician yearly (35). Therefore it is disappointing that only $30 \%$ of the smokers reported having been advised to stop smoking by a physician. The percentage reflects the number of smokers who remember the advice - however, not necessarily the number who have actually been advised.

The subjects exposed to dust or gas did not report that they had received advice to stop smoking from their doctors more often than the unexposed subjects. Many doctors probably do not approach occupational exposures during history taking, and some doctors may not be aware of the excessive risk for lung cancer when asbestos exposure is combined with smoking. Furthermore, it is not known whether this high-risk group of smokers occupationally exposed to gases or dusts would respond more frequently to a physician's advice to stop smoking than unexposed smokers would.

\section{Acknowledgments}

This study was funded by the Royal Norwegian Council for Scientific and Industrial Research, the Norwegian Research Council for Science and the $\mathrm{Hu}$ manities, and the Norwegian Asthma and Allergy Association.

The Central Bureau of Statistics of Norway offered excellent technical assistance during the postal inquiry. Ms V Baste is thanked for her aid with the statistical analysis.

\section{References}

1. United States Department of Health and Human Services. The health consequences of smoking - cancer and chronic lung disease in the workplace: a report of the Surgeon General. Rockville, MD: Office of Smoking and Health, Public Health Service, 1985.

2. Morgan WKC, Seaton A. Occupational lung diseases. 
Philadelphia, PA: WB Saunders Company, 1984.

3. Hilt B, Langård S, Lund-Larsen PG, Lien JT. Previous asbestos exposure and smoking habits in the county of Telemark, Norway - a cross-sectional study. Scand J Work Environ Health 1986;12:561-6.

4. Hammond EC, Selikoff IJ, Seidman H. Asbestos exposure, cigarette smoking and death rates. Ann NY Acad Sci 1979;330:473-90.

5. Central Bureau of Statistics of Norway. Population and housing census 1980: employment statistics. Oslo: Statistisk Sentralbyrả, 1983.

6. Bjartveit K, Foss OP, Gjervig T. The cardiovascular disease study in Norwegian counties. Acta Med Scand Suppl 1983;675:1-184.

7. Gulsvik A. Prevalence of respiratory symptoms in the city of Oslo. Scand J Respir Dis 1979;60:275-85.

8. Dixon JW, ed. BMDP statistical software manual. Berkeley, CA: University of California Press, 1985.

9. Central Bureau of Statistics of Norway. The population and housing census November 1st 1980. Oslo: Statistisk Sentralbyrå, 1981 .

10. Central Bureau of Statistics of Norway. Standard Industrial Classification. Oslo: Statistisk sentralbyrå, 1983.

11. Armitage P, Berry G. Statistical methods in medical research. 2nd ed. Oxford: Blackwell Scientific Publication, 1987.

12. Foss OP, Lund-Larsen PG. Serum thiocyanate and smoking: interpretation of serum thiocyanate levels observed in a large health study. Scand J Clin Invest 1986; 46:245-51.

13. Lee PN. Passive smoking and lung cancer association: a result of bias? Hum Toxicol 1987;6:517--24.

14. Lebowitz MD. Occupational exposure in relation to symptomatology and lung function in a community population. Environ Res 1977;14:59-67.

15. Korn RJ, Dockery DW, Speizer FE, Ware JH, Ferris BG Jr. Occupational exposure and chronic respiratory symptoms: a population-based study. Am Rev Respir Dis $1987 ; 136: 298-304$

16. Krzyzanowski M, Jedrychowski W, Wysocki M. Factors associated with the change of ventilatory function and the development of chronic obstructive pulmonary disease in a 13-year follow-up of the Cracow study. Am Rev Respir Dis 1986;134:1011-9.

17. Thelle DS, Førde OH, Try K, Lehmann EH. The Tromsø heart study. Acta Med Scand 1976;200:107-18.

18. Pierce JP. International comparison of trends in cigarette smoking prevalence. Am J Public Health 1989; 79:152-7.

19. Nielsen PE, Zacho J, Olsen JA, Olsen CA. Ndringer i danskernes rygevaner 1970-87 [Alterations in the Danes' smoking habits in the period 1970-87]. Ugeskr Laeger 1988;38:2229-33. (English abstract.)
20. United States Department of Health and Human Services. Reducing the health consequences of smoking: a report of the Surgeon General. Washington, DC: United States Department of Health and Human Services, 1989.

21. Nicholson WJ, Perkel G, Selikoff IJ. Occupational exposure to asbestos: population at risk and projected mortality 1980-2030. Am J Ind Med 1982;3:259-311.

22. Hillerdal G. Pleural plaques in a healthy survey material: frequency, development and exposure to asbestos. Scand J Respir Dis 1978;59:257-63.

23. Hilt B, Lien JT, Lund-Larsen PG, Lund $K$, Langård $\mathrm{S}$. Asbestos-related findings in chest radiographs of the male population of the county of Telemark, Norway a cross-sectional study. Scand J Work Environ Health 1986;12:567-73.

24. Hillerdal G, Lindgren A. Pleural plaques: correlation of occurrence at autopsy to radiographic findings and occupational history. Eur J Respir Dis 1980;61:315-8.

25. Mowé G, Gylseth B. Occupational exposure and regional variation of malignant mesothelioma in Norway, 1970 79. Am J Ind Med 1986;9:323-32.

26. Svenes KB, Borgersen A, Haaversen O, Holten K. Parietal pleura plaques: a comparison between autopsy and $X$-ray findings. Eur J Respir Dis 1986;69:10-5.

27. Churg A, Warnock ML. Asbestos fibers in the genera population. Am Rev Respir Dis 1980;122:669-78.

28. Churg A. Nonasbestos pulmonary mineral fibers in the general population. Environ Res 1983;31:189-200.

29. De Vuyst P, Durmortier P, Moulin E, Yourassowsky N, Yernault JC. Diagnostic value of asbestos bodies in bronchoalveolar lavage fluid. Am Rev Respir Dis 1987; 136:1219-24.

30. Central Bureau of Statistics of Norway. Standard classification of municipalities. Oslo: Statistisk Sentralbyrå, 1985.

31. Gerhardsson L, Ahlmark A. Silicosis in women: experience from the Swedish Pneumoconiosis Register. J Occup Med 1985;27:347-50.

32. Mowé G, Gylseth B, Hartveit F, Skaug V. Fiber concentration in lung tissue of patients with malignant mesothelioma: a case-control study. Cancer 1985;56: 1089-93.

33. Rosén M, Hanning M, Lindberg G, Nystrøm L. Smoking habits and their confounding effects among occupational groups in Sweden. Scand J Soc Med 1987;15: $233-40$.

34. Li VC, Coates TJ, Ewart CK, Young KJ. The effectiveness of smoking cessation advice given during routine medical care: physicians can make a difference. Am J Prev Med 1987;3:81-6.

35. Sygesikringens Forhandlingsudvalg. Sygesikringsstatistik 1982 [Illness insurance statistics 1982]. Copenhagen: Sygesikringen, 1984.

\section{Appendix}

\section{Questions on smoking habits and occupational exposures ${ }^{\mathrm{a}}$}

\section{Smoking habits}

Do you smoke daily at present? [yes, no]

If the answer was "yes", then answer:

Do you smoke cigarettes daily? (handrolled or factory made) [yes, no]

If you do not smoke cigarettes now, then answer: Have you smoked cigarettes daily before? [yes, no] If you answered "yes", how long has it been since you stopped? [less than 3 months, 3 months to 1 year, 1 to 5 years, more than 5 years]

For those who smoke or have smoked previously.

For how many years altogether have you smoked or did you smoke daily? number of years]

How many cigarettes do you or did you smoke daily? Give number of cigarettes per day (hand-

a The alternatives for the responses are given in brackets at the end of the questions. 
rolled or factory made) cigarettes]

If you smoke, has any physician advised you to stop smoking? [yes, no]

\section{Occupational environment and exposures}

These questions are for those who have been or are employees or are self-employed.

Have you ever had a workplace with much dust or gas in the air? [yes, no]

Have you ever been exposed to asbestos dust in your work? [yes, no]

Received for publication: 9 October 1989
When did you first come in contact with asbestos, please state year?

How many years altogether have you had a job in which you have been exposed to asbestos?

number of years]

To what extent would you say that you have been exposed to asbestos? [slightly, moderately, heavily]

Have you ever been exposed to quartz dust or stone dust with quartz at work? [yes, no]

If yes, please state how many years you have been exposed to such dust at work? [ number of years] 